\title{
Sürdürülebilir İmalata Örnek Damgalama Kalıbı ve Kalıba Uygun Pnömatik Piston Tasarımı ve İmalatı
}

\author{
Mehmet Mahir SOFU*1 \\ 1Isparta Uygulamalı Bilimler Üniversitesi, TBMYO, Makine Programı, 32260, Isparta
}

(Alınış / Received: 25.02.2019, Kabul / Accepted: 29.07.2019)

\section{Anahtar Kelimeler Damgalama kalıbı, Pnömatik piston, Sürdürülebilir imalat, Kalıp imalatı, Plastik şekillendirme}

\begin{abstract}
Özet: Farklı amaçlar ile günümüzde birçok damgalama kalıbı kullanılmaktadır. Damgalama kalıpları sadece büyük sanayilerde değil aynı zamanda küçük atölyelerde de kullanılmaktadır. Genelde sanayide hidrolik güç kullanılarak yapılan damgalama baskılarının küçük atölyelerdeki uygulamaların da kullanılması ilk yatırım maliyetleri ve enerji sarfiyatı açısından oldukça masraflı olabilmektedir. Alternatif olarak hava basıncı ile çalışan pnömatik pistonların kullanılması daha ekonomik ve basit bir işlem olabilmektedir. Fakat metal malzemeler üzerine yapılan damgalama uygulamalarında sistem basıncı yetersizliği nedeni ile pnömatik pistonların oluşturduğu kuvvetler damgala neticesi ile oluşması istenen form için yetersiz kalabilmektedir. Bu çalışmada, tasarımı ve üretimi gerçekleştirilen damgalama zımbasına uygun, atölye ortamında kolay temin edilebilecek bir hava kaynağı ile beslenebilen pnömatik piston hesabı yapılarak imal edilmiștir. İmal edilen damgalama zımbası ve piston ile 5083 alüminyum sac malzeme üzerinde başarılı denemeler gerçekleștirilmiştir. Ayrıca çalışma maksadına uygun özel bir imalat içerdiği düşünülürse sürdürülebilir bir imalata örnek olmuştur.
\end{abstract}

\section{Design and Manufacture of Pneumatic Piston and Stamping Mold Suitable For Sustainable Manufacturing}

\section{Keywords}

Stamping mold,

Pneumatic piston,

Sustainable manufacturing,

Mold manufacturing,

Plastic forming

\begin{abstract}
Today, many stamping molds are used for different purposes. Stamping molds are used not only in large industries but also in small workshops. In general, the use of hydraulic power stamping pressures in small workshops can also be very costly in terms of initial investment costs and energy consumption. Alternatively, the use of air pressure pneumatic pistons can be a more economical and simple process. However, due to the insufficiency of the system pressure in the stamping applications on metal materials, the forces formed by the pneumatic pistons may be insufficient for the form to be formed by the stamping. In this study, it is manufactured with a pneumatic piston calculation which can be fed with an easily supplied air source in the workshop environment, which is designed and produced according to the stamping punch. Successful trials were performed on 5083 aluminum sheet material with stamping punch and manufactured stamp. Moreover, it is an example of a sustainable production considering that it includes a special manufacturing suitable for working purposes.
\end{abstract}

\section{Giriş}

Günümüzde damgalama yöntemi ikiye ayrılmaktadır. İlki sıcak damgalama olarak bilinen bir yöntemdir. Sicak damgalama yöntemi genelde otomotiv sektöründeki saclara şekil vermek için kullanılmaktadır [1]. Sıcak damgalama uygulamasında şekil verilecek malzeme ön bir ısıtma işlemine tabi tutulur. Ön ısıtma malzeme içyapısındaki bağ kuvvetlerini zayıflatır ve kolay şekil alması için yardımcı olur. Bu şekildeki imalatlarda daha az hata ve yüzey bozukluğu oluşur[2]. Soğuk damgalama ise 
özellikle metal pul, para, logo içeren metal saclar üzerine soğuk plastik şekil vermek amacı ile kullanılmaktadır[3]. Damgalama kalıpları için gereken baskı kuvveti için genelde seri hareket içeren eksantrik pres veya hidrolik pres kullanılmaktadır[1]. Bazı ince saçların şekil alması için ise elle tahrik alan presler ya da düşük maliyetlere sahip pnömatik preslerde kullanılmaktadır [4]. Seri üretimi olacak 1$4 \mathrm{~mm}$ kalınlıkta sacların üzerine yapılacak damgalama için gerekli pres gücü bazen elle tahrik alan pres grubu için yetersiz gelmektedir[5]. Diğer taraftan eksantrik preslerin güç aralıkları ise fazla gelebilmektedir. Preslerin baskı güç değerleri Mpa, Bar, Psi değerlerinde standart belli aralıklar ile üretilmektedir[6]. Pres ihtiyacı beklenen güç değerinin pres üreticilerinin belli aralık değerine sahip tablolarından seçilmesi istenmektedir. $\mathrm{Bu}$ durum aslında, istenen gücü karşlayabilecek kapasiteye sahip pres gücünün üzerinde bir güce sahip pres seçilmeye zorlanması anlamına gelmektedir[7]. Pres güçlerinin belli aralıkta seçimi, günümüzde doğal kaynakların etkin kullanımını teşvik eden, düşük atık ve karbon ayak izini sağlayan sürdürülebilir bir imalata uygun değildir. Günümüzde SolidWorks ve vb. gibi yazılımlarda tasarlanan sac modellerinin kalıp maliyetlerini optimum hesaplayan yazılım geliştirme çalışmaları da bulunmaktadır[8][9]. Bu çalışmada istenen form tasarımlarından yola çlkarak basit bir imalat prosesi ile maksadına uygun damgalama kalıbı imalatı yapılmıştır. Aynı zamanda bu kalıpta çalışılacak malzeme göz önüne alınarak gerekli minimum baskı gücüne hasıl, üretim için net gücü karşlayacak düșük maliyetli bir pnomatik pres tasarımı ve imalatı yapılmıştır. Baskı kuvveti için gerekli net güce göre pnömatik piston tasarımı ile sürdürülebilir imalata örnek bir model oluşturmuştur İmal edilen bu pres ile özel tasarıma sahip kalıpta damgalama yöntemi kullanılarak alüminyum malzeme pul üzerinde başarılı şekil verme işlemi gerçekleştirmiştir.

\subsection{Plastik şekil değiştirme durumu}

Damgalama kalıplarında malzemeye plastik şekil verme işlemi kalıplar vasıtasıyla gerçekleştirilir. Uygulanan kuvvet kalıplar vasıtasıyla parçaya iletilir ve gerilmelerin malzemenin akma dayanımını aşması durumunda plastik şekil değiștirme başlar. Pozitif gerilmeler çekme, negatif gerilmeler basma gerilmelerini tarif eder. Gerilme halinin sürdürülmesiyle malzeme kalıbın sahip olduğu şekli alır. Kalıp kullanarak malzemeye plastik şekil verilmesi durumunda çok eksenli bir gerilme hali etkimektedir. Çok eksenli gerilme halinde yapılan deneyler sonucunda görülmüştür ki $\sigma_{1}, \sigma_{2}$, $\sigma_{3}$ şeklinde bahsedilen akma değeri altında kalan asal gerilmelerden bahsedilmektedir. Bu gerilimler altında akmanın başlayabilmesi için farklı isimler ile tarif edilen bazı özel durumların oluşması gerekmektedir. Bu durumlardan ilki;
Von Mises (Distorsiyon Enerjisi) Kriteri: üç eksende oluşan gerilimin eşitlik (1) görülen formülü ile akma şartını tarif eder[10].

$$
\left(\sigma_{1}-\sigma_{2}\right)^{2}+\left(\sigma_{2}-\sigma_{3}\right)^{2}+\left(\sigma_{3}-\sigma_{1}\right)^{2}=2 . \sigma_{0}^{2}
$$

Yukarıdaki eşitlikte $\sigma_{0}$ değeri malzemenin akma dayanımını temsi etmesi durumunda eșitliğin sol tarafının değerinin sağdaki değerinin üzerine çıktığı anda malzemenin şekil değiştirmeye başlayacağını tarif etmektedir. Diğer bir kriter ise Tresca (En Büyük Kayma Gerilmesi) kriteridir. Bu kriterin ifadesini formülü ise (2) de verilmiștir [11].

$$
\sigma_{1}-\sigma_{3}=\sigma_{0}
$$

Eşitliğe göre sol tarafındaki ifadede yer alan malzemeye uygulanan aritmetik olarak en büyük ve en küçük asal gerilmelerin farkı eşitliğin sağ tarafında yer alan malzemenin akma dayanımı $\sigma_{0}$ değerini aştığında akma olayı başlamaktadır. İki akmayı tarif eden kriterin ortak gösterimi şekil 1'de verilmektedir [10] [12].

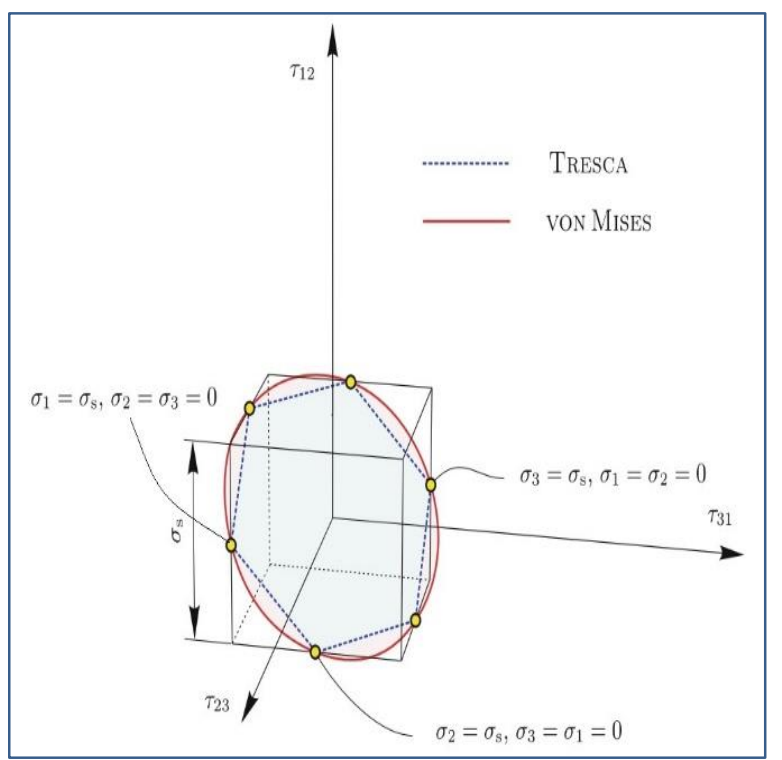

Şekil 1. Von mises ve Tresca kriterlerinin gerilme durumları [12].

Şekil 1'de görüldügü üzere Tresca düzleminde oluşan altıgenin içinde kalan ile Von Mises çemberi içerisinde kalan alanı tarif eden gerilme durumunda akma sınırı içerisinde elastik deformasyonu, bu alanların dıșında ise plastik deformasyon oluşacağı tarif edilmektedir. İki kriterinde de aynı sonuç vereceği görülmektedir. Özellikle ince saçlarda kalıp ile form verilen plastik şekillendirme durumlarında kuvvetin etkidiği yönde veya saç kalınlığı yönünde gerilme taşımadığı düşünülmektedir. Bu durum şu şekilde açıklanabilir; iki Kalıbın arasında sıkıştırılan malzeme şekil değişimi kalıbın boşluğuna doğru şekil 2'de ki gibi akamaya başlayacağı anlamına gelmektedir. Basılan yüzeylerde sürtünmenin etkisi ile şekil değiştirme olmadığı kabul 
edilmektedir. Bu durumda $\sigma_{3}$ veya $\sigma_{2}$ ssfır değerini almaktadır[11].

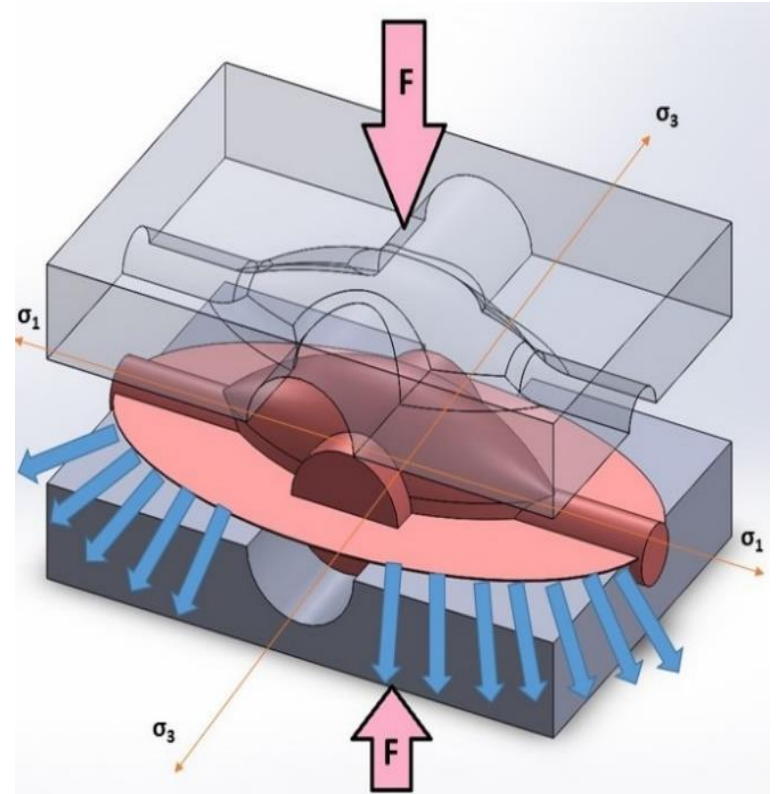

Şekil 2. Kalıp içerisinde sıkıştırılan malzemenin şekil değiștirme durumu ve oluşan gerilimler

Asal gerilmelerin birinin sıfır değerini alması damgalama yönteminde Tresca kriterinin daha gerçekçi sonuçlar verdiği anlamına gelmektedir. Sürtünmenin etkisi göz önünde bulundurularak şekil değişiminin başlaması için akma sınırının genelde \%15 fazlası alınmaktadır. Yani şekil değişme şartı, $1.15 \mathrm{x}_{0}$ şeklinde oluşacak gerilmeye bağlıdır. Damgalama yönteminde kullanılan kalıpların yapısı da akmanın sürtünmeye bağlı etkisi olduğu düşüncesi ile bu çalışmada da şekil değișmenin sınırı için akma sınırının 1.15 katı ile hesaplama yapılmıştır [11] [10].

Malzemelerin akma dayanımının anlık şekil değiştirme gerilim değerini matematiksel olarak hesaplayan fonksiyona literatürde Holloman bağıntısı denildiği bilinmektedir. Holloman bağıntısı (3) de verilen eşitlik ile ifade edilmektedir [13] [10].

$$
\sigma=K \cdot \varepsilon^{\mathrm{n}} \quad(\mathrm{Mpa})
$$

Gerilme değeri; $\boldsymbol{K}$ malzemeye ait özellik olan dayanım sabitine(Mpa) ve $n$ ile ifade edilen şekil değiştirmedeki pekleşme üsteli ne bağlıdır. $\mathrm{n}$ deformasyonun başlaması ile birlikte deformasyonun anlık sertleşmeye ne kadar etkidiği hakkında bilgi vermektedir [1]. Verilen bilgiler ışığında $1 \mathrm{~mm}$ kalınlığında alüminyum saç üzerine, tasarımı yapılan geometrinin damgalama yöntemi ile şekil verilmesini sağlayacak olan zımba üretimi ve şekil değiştirme için yeterli gücü verebilecek bir pnomatik piston hesabı ve üretimi yapılmıştır. Çalışma sonunda zımba ve piston bağlantısı gerçekleştirilerek örnek baskılar alınmıştır.

\section{Materyal ve Metot}

Yapılan deneysel çalıșma șekil 3.' de görülen işlem basamaklarını içermektedir. Bu işlem basamakları

iki farklı ara çalıșma içermektedir. İlk ara çalıșma soğuk şekillendirmede kullanılacak olan zımbanın tasarımı ve üretimini içermektedir. Tasarlanan zımba malzemeye tek taraftan baskı yapacak şekilde planlanmıştır. İkinci ara çalışma tasarımı yapılan zımbaya göre etkin kuvvet üretebilecek pnömatik silindir piston tasarımı ve üretimini içermektedir.

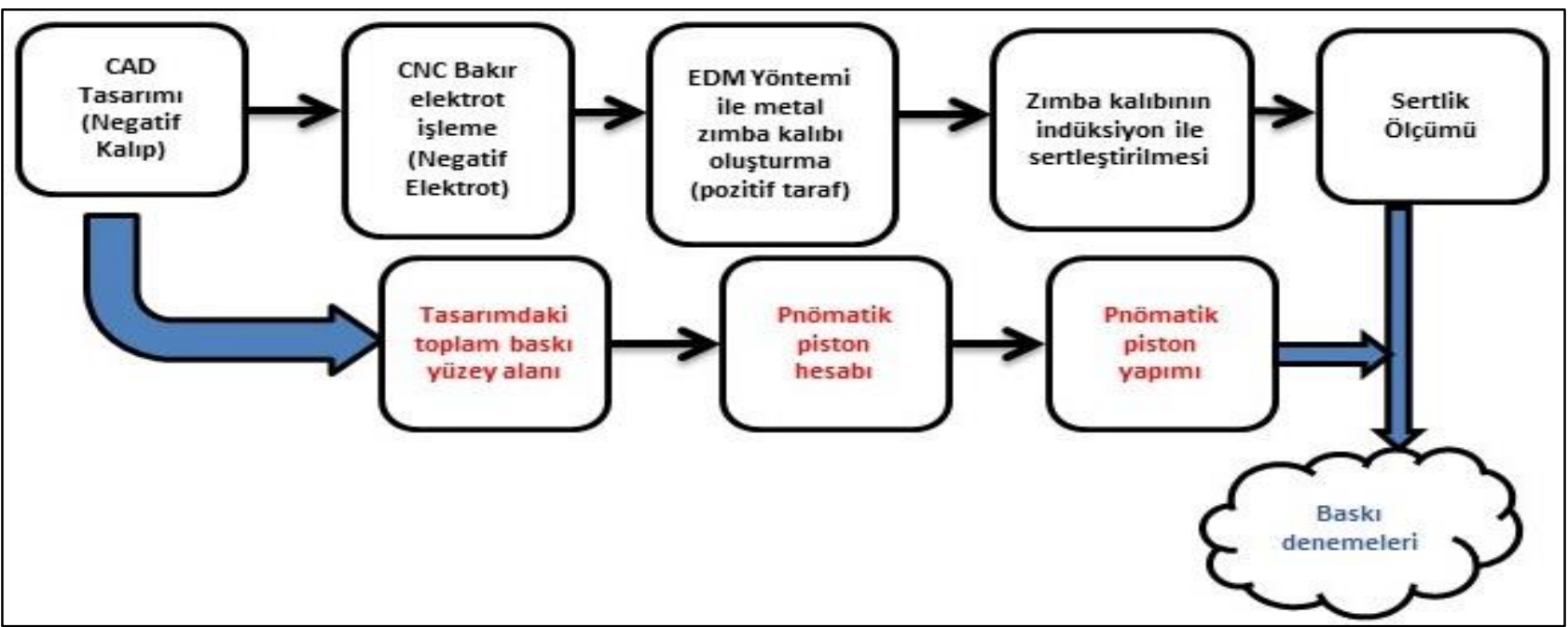

Şekil 3. Damga kalıbı ve Pnomatik presinin imalat akış şeması.

\subsection{Tasarım}

Çalışma ilk önce bilgisayar destekli tasarım ortamında SolidWorks yazılımını kullanarak daha sonra kullanılabilecek görsel bir şekil içeren üç boyutlu katı model tasarımı ile başlanmıştır. Bu tasarımın teknik özellikleri Ø35mm ve baskı derinliği $1 \mathrm{~mm}$ den fazla olması düşünülerek kalıp derinliği $1.5 \mathrm{~mm}$ olarak 
tasarlanmıştır. Bu tasarıma ait katı model görüntüleri görüntüler şekil 4.' de verilmiştir.

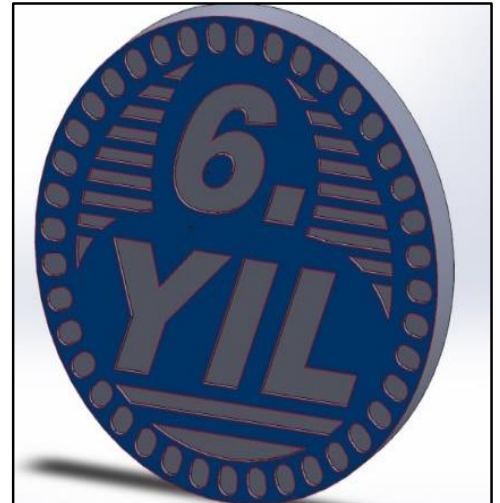

Şekil 4. Ø35mm zımbaya ait üç boyutlu tasarım

Katı model tasarımı tamamlanan geometrinin üzerinden baskı yapacak olan şekil 4.'de mavi renk ile görülen alan CAD ortamında alan hesaplama araçları ile ölçülmüş ve $A=965,65 \mathrm{~mm}^{2}$ hesaplanmıştır. Bu alan pnomatik pres' in piston hesabında kullanılacaktır.

\subsection{Kalıp imalatı}

Bilgisayar ortamında tasarımı tamamlanan 3D katı modelin imalatı için izlenecek yol sadece talaşlı imalat ile gerçekleştirilmesi mümkün olmamaktadır. Geometrinin dik ve dar köşe içermesi nedeni ile bu yerlerde kesicilerin doğal dairesel formları nedeni ile talaş kaldırılamamasına neden olacaktır. Bu durumlarda alışılmamış imalat yöntemlerine başvurmak gerekmektedir. Kalıpçılıkta, bahsi geçen dar ve dik geometrilerin kolayca işlenebilmesi amacı ile literatürde dalma erozyon șeklinde ifade edilen Electro Discharge Machining (EDM) yöntemi yaygın kullanılmaktadır. EDM yönteminde talaş kaldıran takım olarak genelde bakır elektrot kullanılmaktadır. EDM yönteminde Bakıra verilecek her türlü geometri işlenecek metalin sertliği önemli olmadan üzerinden talaş kaldırılarak işlenebilmektedir.

$\mathrm{Bu}$ çalışmada da 3D model üzerindeki geometrinin kalıp üzerinde net çıkabilmesi amacı EDM yöntemi kullanılmıştır. EDM de kullanılacak olan bakır elektrotun talaşlı şekillendirilmesi amacı ile SolidCAM bilgisayar destekli imalat (CAM) operasyonu kullanılmıştır. Bilgisayar ortamında hazırlanan $\mathrm{G}$ ve $\mathrm{M}$ kodları Hardford marka VMC 1020 model CNC dik işleme merkezinde saf bakır elektrot bağlanarak şekil 5.' de görüldügü üzere talaşlı imalatı gerçekleşmiştir. Talaş kaldırma işleminde Makine Takım'ın (HSSE \%8 Co alaşımlı yüksek hız çeliği) $\emptyset 2 \mathrm{~mm}$ parmak freze (düz uçlu) takımı kullanılmıştır. Kesme parametreleri ise, $S=6000 \mathrm{~d} / \mathrm{d} F=650 \mathrm{~mm} /$ dak D.O.C $=0.25 \mathrm{~mm}$ dir.

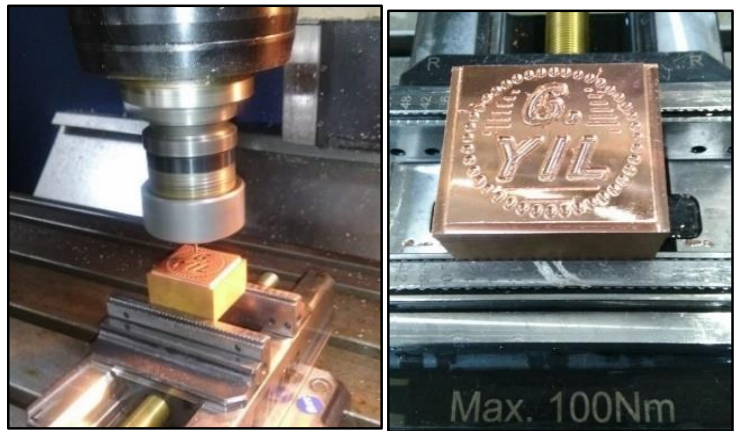

Şekil 5. CNC dik işleme merkezinde EDM için hazırlanan bakır elektrot

Damga kalıbı malzemesi olarak ileride su verilerek sertleştirilmesi düșünüldüğünden $35 \mathrm{mmx} 35 \mathrm{mmx} 35 \mathrm{~mm}$ ebatlarında 1.2379 soğuk iș takım çeliği kullanılmıştır. Normalde talaş kaldırılabilir şekilde yumuşak olan bu çelik Yüksek aşınma direnci, tokluk, yüzey işlemlerine uygunluk, Kolay sertleştirilebilme özelliklerinden dolayı zımba, kesme ve form verme kalıpların oldukça fazla kullanılmaktadır.

Kalıbın son formuna kavuşması amacı ile EDM yöntemine geçilmiştir. EDM işleminde AjanCNC marka CNC özellikli EDM tezgâhı kullanılmıştır. Hazır olan kalıp malzemesi ve kesici takım olarak kullanılacak form verilmiş bakır elektrot kullanılarak şekil 6.'da görüldügü gibi EDM işlemi ile talaş kaldırılmıştır. EDM kesme parametreleri yüzey pürüzlülüğü göz önünde bulundurularak daha sonra kalptaki ince oluşacak ince gözeneklerinden dolayı bu bölgeler üzerinde bir parlatma işlemi yaplamayacağı için finiş parametreleri olarak hazır set olarak tezgah üreticisi firma tarafından hazırlanmış standart düşük amper (7A) içeren parametreler kullanılarak işleme gerçekleştirilmiştir.

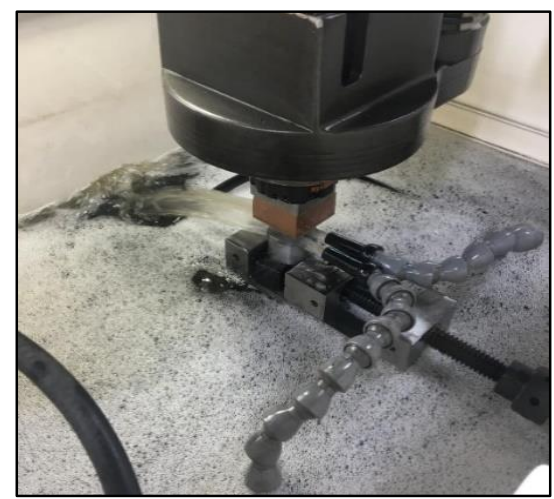

Şekil 6. EDM yöntemi ile damga kalıp zımbasının oluşturulması

EDM sonrası damgalama zımbası üzerinde oluşan form şekil 7.'de verilmiştir. Zımbanın üzerindeki formun ters olması baskı sonrası çıkan üründe oluşturulacak şeklin düz oluşması amacı ile yapılmıştır. 


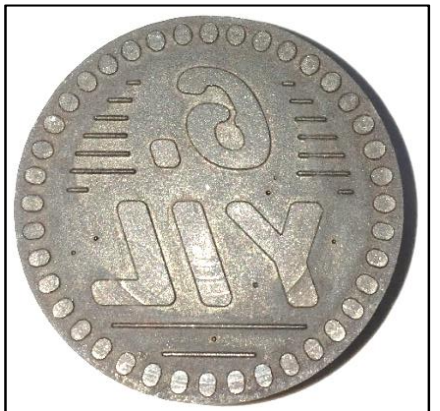

Şekil 7. EDM yöntemi sonrası oluşan damgalama zımbası

Çıkan zımba üzerindeki sertliklerin ölçülerek yeterli mukavemete sahip olup olmadığı ve erken deformasyon olasılığına bağlı yorulma direnci hakkında bir bilgi edinilmesi amacı șekil 8.'de görüldüğü gibi HIGHWOOD marka HWMMT-X model sertlik ölçme cihazı ile ölçülmüștür. Yüzey üzerinden iki farklı noktadan ölçüm yapılmıştr. Ölçümler HRA sertlik birimi cinsinde ölçülmüştür. Ölçüm sonuçları tablo 1.'de yüzey sertleştirme sonuçları ile karşılaştırılmak üzere verilmiştir.

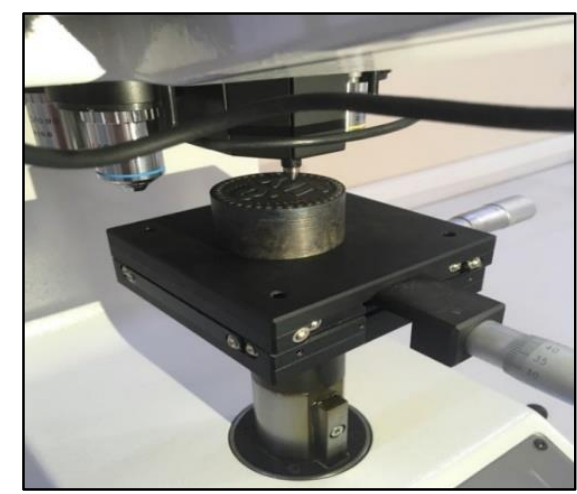

Şekil 8. HIGHWOOD marka HWMMT-X model sertlik ölçme cihazı ile yüzey sertliğinin ölçülmesi

Damgalama zımba elemanının erken deformasyona uğramaması ve baskı oluşacak kuvvetin ezilecek malzemeye homojen aktarılması amacı ile zımba yüzeyine şekil 9. (a)' da görüldüğü üzere sertleştirme işlemi yapılmıştır. Yüzey sertleştirme işleminde kısa sürede ısıtma sağlaması amacı ile manyetik indüksiyon ile ısıtma yöntemi kullanılmıștır. Manyetik indüksiyon isitıcı olarak SPG marka model II cihaz kullanılmıştır. Isıtılan sıcaklıklar termal ölçüm aleti ile ölçülerek $\quad 850-875^{\circ} \mathrm{Ctav}$ sıcaklığına ulaşıldığı görülmüştür. Isıtılan yüzey özel hazırlanan bir düzenek ile șekil 9. (b)’ de görüldügüü üzere su verilerek sertleștirilmiștir.
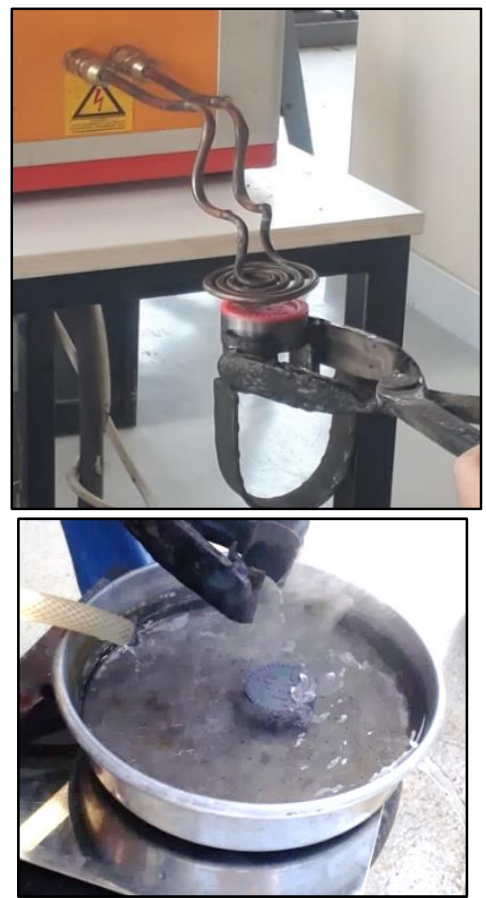

Şekil 9. (a) manyetik indüksiyon ile yüzey tavlama (b) özel düzenek ile su verilme işlemi

Hazırlanan su verme düzeneğinde su seviyesi parçanın toplam yüksekliğinden $2 \mathrm{~mm}$ aşağıda kalacak șekilde su debisi ayarlanmıștır. Yani suyun direk zımba yapacak olan yüzeye teması engellenerek yüzeyde oluşabilecek çarpılmalara veya deformasyonların oluşumu bu şekilde engellenmiştir. Yüzey sertleștirme sonrası tekrar yüzey sertliği iki farklı noktadan ölçülerek Sertleştirme öncesi sertlik değerleri ile birlikte tablo 1.'de verilmiștir.

Tablo 1. Sertleștirme öncesi ve sonrası yüzey pürüzlülük değerleri

\begin{tabular}{|c|c|c|}
\hline $\begin{array}{l}\text { HRA sertlik } \\
\text { sistemi }\end{array}$ & 1. Ölçüm & 2. Ölçüm \\
\hline $\begin{array}{l}\text { Sertleştirme } \\
\text { Öncesi }\end{array}$ & 42 & 43 \\
\hline $\begin{array}{c}\text { Sertlesstirme } \\
\text { Sonrası }\end{array}$ & 55 & 57 \\
\hline
\end{tabular}

Sertleştirme işlemi ile damda kalıbı zımbası kullanıma hazır hale gelmiștir. Sertleştirme öncesi pnomatik pistona bağlantısının sağlanması amacı ile zımbanın ters yüzeyinde M8 cıvata deliği açılmıștır.

\subsection{Pnömatik piston hesabı ve imalatı}

Çalışmada damgalama yöntemi ile baskı alınması düşünülen malzeme piyasada kolayca temin edilebilecek olan alüminyum sac seçilmiştir. Seçilen alüminyum, Tablo 2.'de kimyasal bileşimi verilen 5083 serisi H111 temper'e(sertlik durumu) sahiptir. Seçilen alüminyuma ait Akma gerilmesi değeri ise $\sigma a k=125$ 145(Mpa) olarak verilmektedir. Damgala ile üretilecek 
parçaların hafif olması amacı ile Sac kalınlığı $1 \mathrm{~mm}$ olarak seçilmiştir.

Tablo 2. 5083 serisi alüminyum kimyasal bileşimi

\begin{tabular}{ccccccccc}
\hline Fe & $\mathbf{S i}$ & $\mathbf{C u}$ & $\mathbf{M n}$ & $\mathbf{M g}$ & $\mathbf{Z n}$ & $\mathbf{C r}$ & $\mathrm{Ti}$ & Diğer \\
\hline $\mathbf{0 , 4}$ & \multirow{2}{*}{0,4} & 0,1 & $0,40-$ & $4,0-$ & & $0,05-$ & & \\
& & & 1,0 & 4,9 & 0,25 & 0,25 & 0,15 & 0,15 \\
\hline
\end{tabular}

Üretilen damgalama zımbasının daha önce hesaplanan baskı alanı $A=965,65 \mathrm{~mm} 2$ olarak bilinmektedir. Bu bilgiler damgalama için gerekli piston hesabında; $\sigma a k=145 \mathrm{Mpa}$, ve $A=965,65 \mathrm{~mm} 2$ değerleri kullanılarak şekil değiştirme için gerekli olan kuvvetin hesabı ile başlanılmıștır. (4) bağıntısı ile verilen kuvvet-gerilme formülünden $\mathrm{F}$ kuvveti hesaplanmıștır. Hesaplama sırasında şekil değiştirme sırasındaki sürtünmeler ve pekleşme ile oluşacak direncin aşılması için literatüre de verilen \%15'lik değer artışı eklenmiştir.

$$
1.15 \sigma=\frac{F}{\mathrm{~A}}(\mathrm{kgN} / \mathrm{mm} 2)
$$

Yukarıda verilen eşitlikte alüminyum saca ait akma gerilmesini $145 \mathrm{Mpa}$ ve üzerine işlenecek modelin baskı alanı değerlerini $965,65 \mathrm{~mm} 2$ vererek $\mathrm{F}$ kuvvetinin değeri buradan 140,09KN olarak hesaplanır. Bu değeri elde edebileceğimiz optimum pnömatik piston hesabına geçilmeden pnömatik pistonun yapısının kolay imalatı ve uygun sızdırmazlık elemanlarının(o-ring, keçe vb.) kolay tedarikini düşünerek dairesel olmasına karar verilmiştir. Piston hesabı için eşitlik (5) deki Pnömatik ve hidrolik piston hesaplarında kullanılan basit basınç-kuvvet denklemi kullanılmıştır.

$$
F=P \cdot A \cdot \eta
$$

$\eta$ burada verimi temsil etmektedir. Optimum baskı kuvvetini sağlayacak piston tasarımı için ve bu değer \%80 seçilmiştir. Geriye kalan \%20 değer içerisinde sürtünmeler ve kayıplar için ayrılmıștır.

Eşitlik (5) de piston tasarımına etki edecek en önemli ifade $\mathrm{A}$ ile görünen piston çapı değeridir. Bu çap değerinin bulunması ile uygun pnömatik piston imalatına geçilecektir. $P$ ise pnömatik sistem için gerekli olan sistem basıncı değeridir. Aynı zamanda şekil 10.'da tarif edilen piston yapısındaki silindir boşluğunda oluşacak basınca da eșit olacaktır.

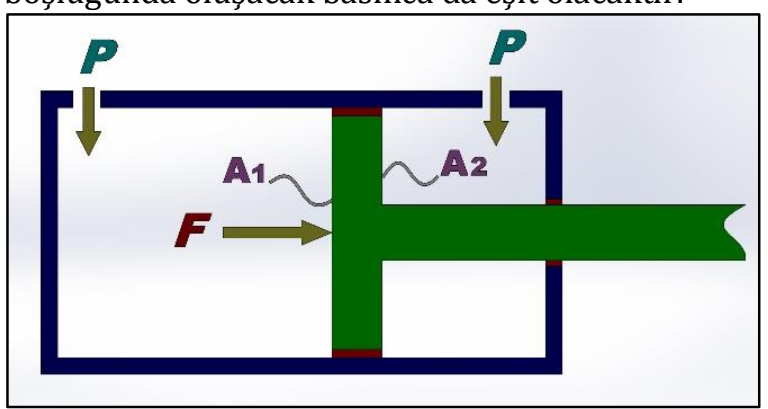

Şekil 10. Tasarlanan pnömatik piston kesit görünüşü
Sistem basıncı, çalışmanın gerçekleştiği S.D.Ü. YETEM merkezi Tasarım ve İmalat birimi atölyesinde rutin hava ihtiyacı için kullanılan vidalı tip kompresör ile 810 bar arası elde edilmektedir. Bu ilgiler ışığında (5) numaralı eşitlikte $F=140,09 \mathrm{KN}, \eta=0,8$ ve sistem basıncı için minimum değer olan $P=8$ bar alınmıștır. $P=8$ bar $=0,0008 \mathrm{Kn} / \mathrm{mm} 2$ dönüşümü ile eşitlikte $A$ değeri çekilerek hesaplanmıştır. Alan değeri $A=$ $218890,625 \mathrm{~mm}^{2}$ hesaplanmıştır. Silindirik pistona ait dairesel yüzeyin çapı ise $d=527,92 \mathrm{~mm}$ şeklinde bulunmuştur. Tam ölçüde imalatı gerçekleşmesi amacı ile piston çapı $d=550 \mathrm{~mm}$ olarak alınarak pnömatik piston imalatına başlanmıştır. Pnömatik pistonun imalatı için Isparta sanayisinde Pnömatik kesme kalıpları ve pistonları imalatı yapan Kripto kalıp ltd. şti. firmasından hizmet alımı yapılarak bu çalışma için $d=550 \mathrm{~mm}$ çapta özel pnömatik piston imalatı yapmıştır. İmalatı gerçekleşen piston şekil 11 'de görülmektedir.

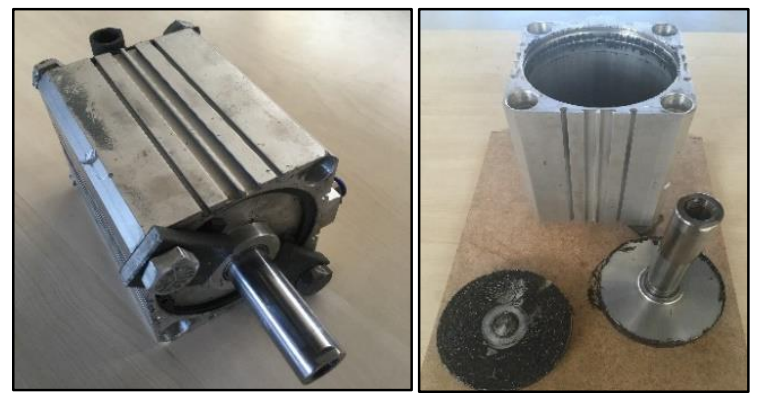

Şekil 11. Kripto kalıp tarafından yapılan piston görünüşü

\section{Bulgular}

Çalışmanın sonunda imal edilen damgalama zımbası ve pnömatik pistonun tüm parçalarının montajı şekil 11.'de ki gibi toplanmış baskı için hazır hale getirilmiștir. Pistonun sabitlenmesi ve piston kuvvetinin tam doğrusal aktarılması adına piston ve kalıbın yerleştirilebileceği sac yapıda bir gövde şekil 11 'deki gibi tasarlanarak imal edilmiștir. Montajı tamamlanan sistemin hava ile bağlantısı da çeşitli pnömatik elemanlar ile tamamlanarak baskı yapacak şekle getirilmiştir. Hazır şekilli kesim $(\varnothing 35 \mathrm{~mm})$ sipariş edilen alüminyum malzemeler üzerinde baskı denemelerine geçilmiş ve baskıların neticesinde șekil 12 'de göründüğü üzere tek yüzeyden yapılan damgalama ile zımba üzerindeki şeklin alüminyum parça üzerine yeterli iz bırakması sağlanmıștır. 


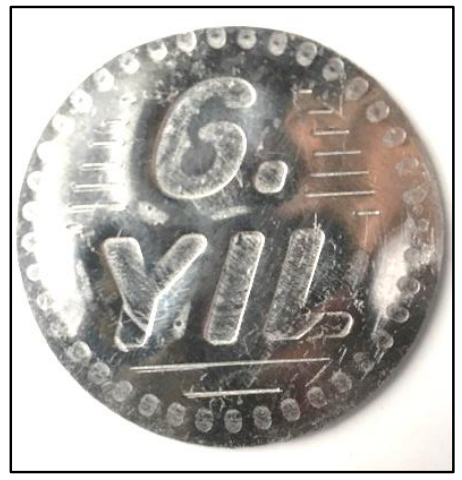

Şekil 12. Zımbalanmış alüminyum üzerindeki baskı görüntüsü

Zımba kalıbı ile yapılan 100 adedin üzerindeki baskılarda çıkan numunelerin üzerinden farklı bölgelerden baskı derinlikleri iğne uçlu mikrometre ile ölçülerek 0,35-0,58mm arasında değerlere sahip baskı derinlikleri ölçülmüştür. Eğer damgalama sırasında alüminyum malzeme altına kauçuk gibi sert plastik malzeme konulur ise baskı şekillerinin daha net belirdiği gözlemlenmiştir. Bunun nedeni ise eşitlik üçte verilen Holloman bağıntısında bulunan $\mathrm{n}$ şekil değiștirmedeki pekleșme üstelinin şekil değiștirmeye yardımcı olan yumuşak tabanın yardımı ile düşük değerde kalmasına neden olduğu düşünülmüștür. Bu şekilde şekil değiştirmenin daha kolay olduğu görülmüştür.

Ayrıca, kalıp zımbasının CAD-CAM-CNC zinciri kullanılarak imalatı gerçekleştirilmiş olup zımbanın manyetik indüksiyon kullanılarak sertleştirilmesi imalat sürecinin çok hızlı tamamlanmasına neden olmuştur. Manyetik indüksiyon yöntemi kullanılarak elde edilen yüzey sertliği \%30 oranında arttırılmıştır.

\section{Tartışma ve Sonuç}

Çalışmada, bilgisayar destekli tasarım programı ile tasarlanan bir modelin damgalama yöntemi ile üretimi için gerekli pnömatik pistonun maksadına uygun olarak sürdürülebilir bir imalat ile üretile bileceği görülmüştür. Uygulamada daha yüksek güçlerde çalışma aralıklarından seçilmek zorunda kalınan pnömatik pistonlar yerine daha az malzeme ve hurda ile düşük maliyette üretim yaparak maksadına uygun pnömatik pistonların kullanılabileceği görülmüştür. Çalışma ayrıca göstermiştir küçük atölyelerde kullanıma uygun rutin kullanılan hava kaynağı (8-10 Bar)ile besleme yapılarak basit damgalama işlemi gerçekleştirilebilecektir. Yüksek yatırım maliyetleri ve işletme giderlerine sahip hidrolik ünitelerin kullanılmasının gerek olmadığı görülmüştür.

\section{Teşekkür}

Çalışmanın tüm süreçlerinde görev alan, Dursun KARAGÖL, İlyas YERLİKAYA, Yılmaz GENCER, Üzeyir EMEN'e ile S.D.Ü. YETEM merkezi tasarım ve imalat birimine, katkılarından dolayı ISUBU TBMYO müdürlüğüne teşekkür ederim.

\section{Kaynakça}

[1] Bedir, F., Durak, E., Delikanll, K., 2006. Alüminyum Alaşımlarının Otomotiv Endüstrisinde Uygulanıla bilirliği ve Mekanik Özellikleri, Mühendis ve Makine, Cilt:47, (555), 37-46.

[2] Altan, T., Tekkaya, A. E., editors 2012. Sheet Metal Forming Processes and Applications. ASM International, 381s.

[3] Groover, M.P. 2010. Fundamentals of modern manufacturing: materials, processes and systems, 4th ed. John Wiley \& Sons, Inc., 1028s.

[4] Aykaç, E. S. 2011. Pnömatik-Hidrolik. TMMOB Makina Mühendisleri Odası Ankara

[5] Lim, Y., Venugopal, R., Ulsoy, A. G., 2014. Process Control for Sheet-Metal Stamping, SpringerVerlag, London, 146s.

[6] Üçüncü, K. 2016. Hidrolik ve Pnömatik sistemler. aves.ktu.edu.tr/ImageOfByte.aspx?Resim=8\&SS NO=155\&USER $=4049$ (Erişim Tarihi: 06.10.2018).

[7] Hou, M., 1997. Stamp forming of continuous glass fibre reinforced polypropylene, Composites Part A, 28A (1997), 695-702.

[8] Efendioğlu, Ş., gürün H.,, Çavuşoğlu, O. 2015. Prograsif Sac Metal Kalıplama İşlemlerinde Kalıp Maliyet Modeli Geliştirilmesi. Gazi University Journal of Science, part c, 3(2015),(4),585-594

[9] Cheok, B.T., Nee, A.Y.C., 1998. Trends and developments in the automation of design and manufacture of tools for metal stampings. Journal of Materials Processing Technology, 75 (1998), 240-252.

[10] Demirkol, M. 2010. Plastik şekil verme teknolojisi ders notları. https://web.itu.edu.tr/gulmezt/IMAL \%20USULLERI/Groover\%20PSV\%20TUR.pdf (Erişim Tarihi: 21.10.2018).

[11] Koistinen, D. P., Wang, N-M. 1978. Mechanics of Sheet Metal Forming Material Behavior and Deformation Analysis. Plenum Press, New York. 411s.

[12] Kolupaev, V. A., Yu, M.-H, Altenbach, H. 2013. Yield criteria of hexagonal symmetry in the $\pi$ pane. Acta Mech, 224(2013), 1527-1540s. 
[13] Seo, K.-Y., Kim, J.-H., Lee, H.-S., Kim, J.H., Kim, B.M. 2017. Effect of Constitutive Equations on Springback Prediction Accuracy in the TRIP1180 Cold Stamping. Metals journal, 8(2018), 18.

[14] SolidWorks, SolidCAM, 2018, Teknolojik Yazılımlar, BüyükdereCad, Stad Han 85, Mecidiyeköy, İstanbul. 